\title{
DISTRIBUSI KERAGAMAN GENETIK POPULASI Santalum album BERDASARKAN PENANDA RAPD
}

Genetic Diversity and Its Distribution of Santalum album Populations Revealed by RAPD Markers

\section{Anto Rimbawanto, AYPBC Widyatmoko dan Purnamila Sulistyowati}

Pusat Litbang Hutan Tanaman

\begin{abstract}
Santalum album (sandalwood) is a high value timber native to the Island of Timor, Sumba and Flores, eastern in Indonesia. The aim of this study is to investigate genetic variation and genetic relationship between population to support genetic conservation and breeding program of the species. Leaves of from 17 populations were collected and analyzed using 17 RAPD primers which produced 34 polymorphic loci. The average polymorphic locus for each primer was two. The average genetic diversity within population was 0.391, while between populations was 0.038. Cluster analyses based on population data revealed that the 17 populations were divided into 2 big groups. In general the clustering of the populations did not reveal clear relationsip with geographic distribution, however geographically closed populations were tent to cluster into small group.
\end{abstract}

Key words: Conservation, genetic diversity, RAPD, Santalum album

\begin{abstract}
ABSTRAK
Santalum album atau yang dikenal dengan nama cendana merupakan jenis kayu bernilai tinggi dan telah mengalami degradasi sumber genetik yang serius. Jenis ini merupakan tanaman asli Propinsi Nusa Tenggara Timur. Penelitian ini bertujuan untuk mengetahui keragaman genetik dan hubungan kekerabatan populasi Santalum album untuk mendukung program konservasi dan pemuliaan jenis tersebut. Sampel daun dikumpulkan dari 17 populasi dan dianalisa menggunakan 17 primer RAPD yang menghasilkan 34 lokus polimorfik. Rata-rata lokus polimorfik per primer adalah 2. Nilai ratarata keragaman genetik dalam populasi sebesar 0,391 sedangkan keragaman antara populasi 0,038. Analisis klaster membagi 17 populasi menjadi dua kelompok besar. Secara umum pembagian kelompok tidak memperlihatkan hubungannya dengan jarak geografis, tetapi populasi-populasi yang berdekatan mempunyai kecenderungan untuk membentuk satu sub-kelompok.
\end{abstract}

Kata Kunci: Keragaman genetik, konservasi, RAPD, Santalum album 


\section{PENDAHULUAN}

Santalum album (cendana) merupakan salah satu jenis hasil hutan penting di Indonesia, khususnya di Propinsi Nusa Tenggara Timur. Tiga pulau utama dari sebaran cendana adalah Timor, Flores dan Sumba. Eksploitasi cendana sudah dilakukan sejak abad 10 dan dilakukan terus-menerus tanpa didukung penanaman kembali yang memadai. Hal ini mengakibatkan menurunnya sumber genetik cendana secara cepat. Selain itu penanaman cendana menjadi kurang menarik karena minyak baru bisa diperoleh setelah kayu terasnya muncul, padahal jenis ini pertumbuhannya lambat. Dengan semakin menurunnya potensi sumber genetik cendana, maka perlu dilakukan upaya konservasi guna menjaga dan mempertahankan sumber genetik yang masih tersisa. Selain itu, untuk mendukung pengembangan penanaman jenis ini juga perlu dilakukan kegiatan pemuliaan untuk memperoleh bibit yang lebih unggul.

Informasi mengenai keragaman genetik sangat diperlukan untuk mendukung kegiatan konservasi dan pemuliaan. Besarnya keragaman genetik mencerminkan sumber genetik yang diperlukan untuk adaptasi ekologi dalam jangka pendek dan evolusi dalam jangka panjang (Lande and Shannon, 1996).

Penanda molekuler banyak digunakan dalam kegiatan analisis keragaman genetik tanaman, salah satunya adalah Random Amplified Polymorphic DNA (RAPD) (Welsh and McClelland, 1990; Williams et al., 1990). RAPD adalah penanda berbasis PCR (Polymerase Chain Reaction) dengan menggunakan 10-mer primer acak.

Tujuan dari kegiatan penelitian ini adalah untuk mengetahui keragaman genetik dan hubungan kekerabatan populasi $S$. album. Informasi genetik ini bermanfaat untuk program konservasi dan pemuliaan jenis tersebut.

\section{BAHAN DAN METODE}

\section{A. Bahan Penelitian}

Materi genetik yang digunakan dalam penelitian ini adalah daun yang berasal dari 17 populasi di Propinsi Nusa Tenggara Timur dan Jawa. Ketujuh belas populasi tersebut adalah Polen, Bu'at, Oenlasi, Aen Ut, Kuma', Haumeni, Snok, Noemuti, Amanuba Selatan, Amanuba Tengah (Pulau Timor), Omtel, Pailelang, Waisika (Pulau Alor), Katikutana, Hambala, Mondu (Pulau Sumba) dan Karangmojo (Jawa). Masing-masing populasi diwakili oleh 12 sampel.

\section{B. Metode Penelitian}

\section{Ekstraksi DNA dan prosedur RAPD}

Untuk memperoleh total DNA, daun dari masing-masing individu diekstraksi dengan metode CTAB (Murray and Thompson, 1980) yang telah dimodifikasi (Shiraishi and Watanabe, 1995). Daun seberat $50 \mathrm{mg}$ dihancurkan dalam larutan ekstraksi dengan menggunakan mesin penghancur MiniBead Beater-8 (BioSpec) selama 5 menit, dan diinkubasi selama 1 jam dalam suhu $65^{\circ} \mathrm{C}$. Hasil ekstraksi dimurnikan (dipurifikasi) menggunakan GeneClean III Kit (Q-Biogene). Konsentrasi DNA dikuantifikasi menggunakan GeneQuant (Pharmacia), selanjutnya dilarutkan menjadi 2,5 ng/il untuk reaksi PCR.

Reaksi PCR dilakukan dengan total volume 10 ì volume yang mengandung 1x Buffer (10 mM Tris- $\mathrm{HCl}$ (pH8.3), $10 \mathrm{mM} \mathrm{KCl}, 3,0 \mathrm{mM} \mathrm{MgCl}$ ), $200 \mathrm{uM}$ tiap dNTP, 0,25 uM primer, 0,5 units/10 ul AmpliTaq DNA polymerase, Stoffel Fragment (Applied Biosystem), 10 ng larutan DNA. Proses PCR diawali dengan denaturasi selama 60 detik pada suhu $94^{\circ} \mathrm{C}$, diikuti dengan 45 siklus yang masingmasing terdiri dari denaturasi selama 30 detik pada suhu $94^{\circ} \mathrm{C}$, annealing (penempelan primer) selama 
30 detik pada suhu $37^{\circ} \mathrm{C}$, dan extention (pemanjangan) selama 90 detik pada suhu $72^{\circ} \mathrm{C}$. Proses PCR diakhiri dengan pemanjangan selama 7 menit pada suhu $72^{\circ} \mathrm{C}$. Keseluruhan proses tersebut menggunakan thermocycler GeneAmp 9700 (Applied Biosystems). Hasil amplifikasi PCR dielektroforesis pada 1,0\% gel agarose, $20 \mathrm{X}$ TBE Buffer dan 0.5\% Ethidium Bromide selama \pm 2 jam pada $120 \mathrm{~V}$. Hasil elektroforesis difoto menggunakan Fotodyne Image Analyzer. Jumlah primer RAPD yang digunakan dalam studi ini adalah 17 primer. Nama primer yang digunakan beserta susunan basanya disajikan pada Tabel 1 .

\section{Analisis Data}

Jarak genetik dihitung berdasarkan pengukuran Nei's (Nei, 1978) dengan mempergunakan bantuan program komputer POPGENE 1.32 (Yeh et al.,1999). Dendrogram menggunakan metode UPGMA dibuat menggunakan data jarak genetik tersebut untuk mengetahui hubungan kekerabatan antar indiviđu dan antar populasi.

\section{HASIL DAN PEMBAHASAN}

\section{A. Keragaman Genetik}

Analisis RAPD menggunakan 17 primer terhadap keempat populasi menghasilkan 34 loci polimorfik. Panjang lokus polimorfik berkisar antara $250 \mathrm{bp}$ - $1100 \mathrm{bp}$. Jumlah lokus yang dihasilkan oleh masing-masing primer berkisar antara satu sampai empat dengan rata-rata 2 loci per primer disajikan pada Tabel 1 .

Tabel 1. Daftar primer yang digunakan beserta susunan basanya dan jumlah pita polimorfik yang dihasilkan.

\begin{tabular}{|c|c|c|c|}
\hline No. & Primer & $\begin{array}{c}\text { Sekuens } \\
(5-3)\end{array}$ & $\begin{array}{c}\text { Jumlah pita } \\
\text { polimorfik }\end{array}$ \\
\hline 3 & OPA-10 & GTGATCGCAG & 3 \\
\hline 4 & OPA-16 & AGCCAGCGAA & 2 \\
\hline 5 & OPA-17 & GACCGCTTGT & 3 \\
\hline 6 & OPG-06 & GTGCCTAACC & 2 \\
\hline 1 & OPG-14 & GGATGAGACC & 1 \\
\hline 7 & OPG-15 & ACTGGGACTC & 1 \\
\hline 2 & OPK-17 & ACGACCGACA & 2 \\
\hline 8 & OPK-16 & GAGCGTCGAA & 1 \\
\hline 9 & OPK-20 & GTGTCGCGAG & 4 \\
\hline 10 & OPP-02 & TCGGCACGCA & 1 \\
\hline 11 & OPP-03 & CTGATACGCC & 1 \\
\hline 12 & OPP-05 & CCCCGGTAAC & 2 \\
\hline 13 & OPP-08 & ACATCGCCCA & 3 \\
\hline 14 & OPP-18 & GGCTTGGCCT & 3 \\
\hline 15 & OPS-12 & CTGGGTGAGT & 2 \\
\hline 16 & OPZ-11 & CTCAGTCGCA & 2 \\
\hline 17 & OPZ-12 & TCAACGGGAC & 1 \\
\hline \multicolumn{5}{|c|}{ Total } & 34 \\
\hline \multicolumn{4}{|c}{} \\
\hline
\end{tabular}

Nilai keragaman genetik berdasarkan analisis keragaman genetik Nei $(1972 ; 1973)$ bervariasi antara 0,321 sampai 0,443. Keragaman tertinggi dimiliki oleh populasi Kuma' (Timor), sedangkan yang terendah adalah Amanuba Selatan (Timor). Rata-rata keragaman genetik di dalam populasi adalah 0,391 (Tabel 2). 
Dengan menggunakan 17 primer RAPD yang menghasilkan 34 lokus polimorfik, rerata keragaman genetik dari populasi yang dianalisis adalah sebesar 0,391. Angka ini lebih besar dari pada rata-rata keragaman genetik baik untuk kelompok jenis tropis maupun jenis konifer, yaitu 0,211 dan 0,207 (Hamrick, 1989). Besarnya keragaman genetik ini diduga disebabkan karena beberapa hal. Pendugaan yang pertama adalah bahwa lokus polimorfik yang digunakan dalam analisis ini sudah dipilih yang mempunyai frekuensi yang tinggi. Pendugaan yang kedua adalah bahwa memang populasi masih tersisa memiliki keragaman yang masih tinggi, di mana tingginya keragaman genetik ini sudah dimiliki sejak terbentuknya jenis ini dan dalam proses ekologinya. Shashidhara et al. (2003) melaporkan bahwa keragaman genetik $S$. album di India menggunakan RAPD masih cukup tinggi.

Besarnya nilai rata-rata jarak genetik antar populasi adalah 0,038 . Dengan kata lain, sekitar $96 \%$ dari keragaman genetik berada di dalam populasi. Hubungan terdekat diperlihatkan antara populasi Aen Ut dan Kuma' (Sumba), sedangkan jarak genetik yang terjauh adalah antara populasi Mondu dan Katikutana (Sumba) dengan jarak genetik sebesar 0,111.

Rata-rata jarak genetik antar populasi dari keempat populasi adalah 0,038 lebih kecil daripada Intsia palembanica $(0,04$; Lee et al., 2002) dan Shorea leprosula $(0,04$; Rimbawanto dan Suharyanto, 2005). Rendahnya jarak genetik ini disebabkan karena populasi cendana yang ada di NTT pada awalnya merupakan satu populasi besar yang tidak terpisah. Kecenderungan pola distribusi keragaman seperti ini di mana keragaman genetik di dalam populasi jauh lebih besar daripada antar populas seperti yang dilaporkan juga pada Shorea leprosula (Rimbawanto dan Suharyanto, 2005), dapat disebabkan oleh sistem perkawinan (mating system), sejarah populasi dan spesiasi, sebaran populasi, letak geografis, dan gene flow; dan spesies yang berkawin silang, berdaur hidup panjang, sebarannya yang luas dan berkesinambungan dengan populasi yang besar (Hamrick and Godt, 1989).

Kedua hasil di atas, baik keragaman genetik di dalam maupun antar populasi berbeda dengan yang dilaporkan oleh Suma dan Balasundaran (2003), yaitu bahwa 78,3\% keragaman genetik berada di antara populasi, sedangkan sisanya $21,7 \%$ berada di dalam populasi. Hal ini disebabkan karena terjadinya fragmentasi pada populasi awal yang sangat luas, rendahnya gen flow antar populasi dan perbedaan populasi akibat random drift.

Tabel 2. Nilai keragaman genetik dalam populasi (diagonal) dan antar populasi (bawah diagonal) Merbau berdasarkan Nei's Gene Diversity (1973) dan Nei's Original Measures of Genetic Distance (1972)

\begin{tabular}{|c|c|c|c|c|c|c|c|c|c|c|c|c|c|c|c|c|c|}
\hline Pop & 1 & 2 & 3 & 4 & 5 & 6 & 7 & 8 & 9 & 10 & 11 & 12 & 13 & 14 & 15 & 16 & 17 \\
\hline 1 & 0,387 & & & & & & & & & & & & & & & & \\
\hline 2 & 0,015 & 0,437 & & & & & & & & & & & & & & & \\
\hline 3 & 0,034 & 0,007 & 0,412 & & & & & & & & & & & & & & \\
\hline 4 & 0,036 & 0,010 & 0,038 & 0,414 & & & & & & & & & & & & & \\
\hline 5 & 0,032 & 0,019 & 0,021 & 0,041 & 0,358 & & & & & & & & & & & & \\
\hline 6 & 0,008 & 0,012 & 0,029 & 0,015 & 0,027 & 0,414 & & & & & & & & & & & \\
\hline 7 & 0,026 & 0,001 & 0,003 & 0,007 & 0,031 & 0,019 & 0,443 & & & & & & & & & & \\
\hline 8 & 0,016 & 0,010 & 0,003 & 0,030 & 0,027 & 0,008 & 0,021 & 0,382 & & & & & & & & & \\
\hline 9 & 0,061 & 0,048 & 0,053 & 0,099 & 0,046 & 0,040 & 0,071 & 0,047 & 0,379 & & & & & & & & \\
\hline 10 & 0,019 & 0,003 & 0,009 & 0,022 & 0,007 & 0,010 & 0,012 & 0,005 & 0,030 & 0,397 & & & & & & & \\
\hline 11 & 0,042 & 0,007 & 0,001 & 0,042 & 0,004 & 0,026 & 0,024 & 0,026 & 0,050 & 0,013 & 0,403 & & & & & & \\
\hline 12 & 0,031 & 0,019 & 0,014 & 0,023 & 0,018 & 0,022 & 0,020 & 0,021 & 0,066 & 0,009 & 0,014 & 0,406 & & & & & \\
\hline 13 & 0,025 & 0,028 & 0,019 & 0,010 & 0,054 & 0,031 & 0,014 & 0,015 & 0,098 & 0,040 & 0,059 & 0,021 & 0,411 & & & & \\
\hline 14 & 0,016 & 0,008 & 0,006 & 0,028 & 0,006 & 0,007 & 0,008 & 0,002 & 0,053 & 0,003 & 0,001 & 0,010 & 0,029 & 0,407 & & & \\
\hline 15 & 0,082 & 0,070 & 0,043 & 0,082 & 0,051 & 0,058 & 0,061 & 0,056 & 0,066 & 0,049 & 0,071 & 0,067 & 0,062 & 0,056 & 0,321 & & \\
\hline 16 & 0,078 & 0,072 & 0,037 & 0,110 & 0,082 & 0,070 & 0,075 & 0,045 & 0,078 & 0,052 & 0,058 & 0,065 & 0,093 & 0,059 & 0,065 & 0,335 & \\
\hline 17 & 0,081 & 0,067 & 0,049 & 0,111 & 0,063 & 0,070 & 0,076 & 0,052 & 0,073 & 0,050 & 0,048 & 0,068 & 0,093 & 0,040 & 0,049 & 0,003 & 0,348 \\
\hline
\end{tabular}

Keterangan (nama populasi):

1, Omtel; 2, Aen Ut; 3, Hambala; 4, Katikutana; 5, Waisika; 6, Pailelang; 7, Kuma'; 8, Polen; 9, Karangmojo; 10, Oenlasi; 11, Haumeni; 12, Snok; 13, Noemuti; 14, Bu'at; 15, Amanuba Selatan; 16, Amanuba Tengah; 17, Mondu. 


\section{B. Hubungan Kekerabatan Antar Populasi}

Berdasarkan jarak genetik Nei (1972) disusun dendrogram menggunakan metode UPGMA untuk mengklarifikasi hubungan antar populasi (Gambar 1). Dendrogram tersebut menunjukkan hubungan kekerabatan antara populasi yang dianalisis. Populasi-populasi yang dianalisis terbagi menjadi 2 kelompok besar. Kelompok pertama terdiri dari Amanuba Selatan, Amanuba Tengah dan Mondu, sedangkan sisanya membentuk kelompok kedua. Kelompok kedua juga masih dapat dibagi lagi menjadi 3 sub-kelompok kecil. Sub kelompok pertama terdiri dari yaitu Omtel, Pailelang, Polen, Bu'at dan Oenlasi, sub-kelompok kedua terdiri dari Aen Ut, Kuma' dan Katikutana, sedangkan Hambala, Haumeni, Waisika dan Snok membentuk sub-kelompok ketiga. Populasi Noemuti dan Karangmojo berdiri sendirisendiri di dalam kelompok dua.

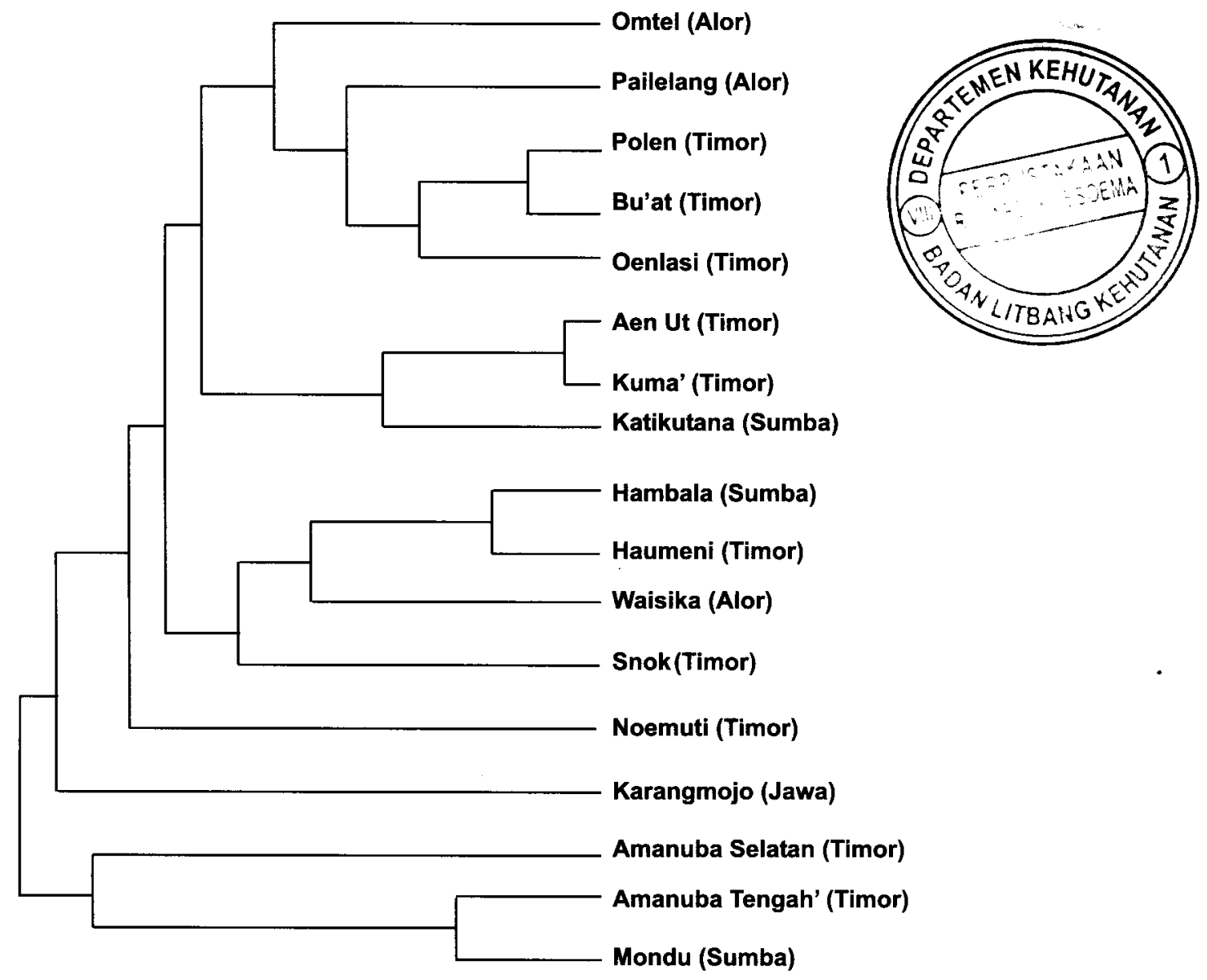

Gambar 1. Dendogram hubungan kekerabatan antara 17 populasi cendana berdasarkan jarak genetik Nei's (1972)

Secara garis besar, pengelompokan yang terjadi tidak berhubungan nyata dengan posisi geografisnya. Tetapi apabila dilihat ke dalam sub-kelompok yang terbentuk, ada kecenderungan bahwa populasi yang berasal dari pulau yang sama membentuk sub-kelompok yang sama. Salah satu penyebabnya adalah bahwa penanda RAPD yang digunakan memperlihatkan variasi DNA baik pada coding maupun noncoding regions. Sebab yang lain adalah karena hubungan kekerabatan antar populasi yang sangat rendah sehingga pengelompokan populasi tersebut menjadi bias.

Populasi Karangmojo, yang merupakan hasil penanaman mempunyai keragaman genetik 0,379. Populasi ini termasuk dalam kelompok besar dan tidak membentuk sub-kelompok. Diduga materi genetik yang digunakan untuk penanaman tidak berasal dari satu populasi. 
Melihat pengelompokan yang terjadi, di mana populasi Amanuba Selatan, Amanuba Tengah dan Mondu membentuk satu kelompok, dan melihat jarak genetik antar populasi yang ada (sangat rendah), diduga penyebabnya adalah besarnya eksploitasi yang dilakukan pada ketiga populasi tersebut sehingga menyebabkan menurunnya keragaman genetik yang dimiliki oleh ketiga populasi tersebut. Hal ini dibuktikan dengan kecilnya keragaman genetik dari ketiga populasi tersebut dibandingkan dengan populasi lainnya.

Pola pengelompokkan populasi dan jarak genetik memperlihatkan hubungan yang nyata dengan distribusi geografis populasi ulin. Populasi Samboja, Meratus, dan S. Wain berada dalam satu kelompok karena letaknya berdekatan. Populasi S. Wain dan Samboja yang mempunyai hubungan terdekat secara geografis di lapangan kedua populasi ini letaknya berdampingan. Populasi Lempake terpisah dari kelompok populasi lainnya dan mempunyai jarak genetik yang relatif tinggi terhadap populasi-populasi lainnya terletak berjauhan dengan populasi-populasi lainnya. Penelitian terhadap populasi Shorea leprosula Miq. (Rimbawanto dan Suharyanto, 2005) menunjukkan terdapat korelasi antara jarak genetik dan letak geografis.

\section{KESIMPULAN}

1. Rata-rata keragaman genetik di dalam populasi dari 17 populasi Santalum album yang diteliti adalah $0,391 \pm 0,034$.

2. Rata-rata jarak genetik antar populasi adalah sebesar $0,038 \pm 0,027$, yang berarti bahwa sekitar $96 \%$ keragaman genetik berada di dalam populasi, sedangkan sisanya $4 \%$ berada di antara populasi. Analisis kluster dengan metode UPGMA, membagi tujuh belas populasi ke dalam dua kelompok besar, yang masing-masing terdiri dari 3 populasi dan 14 populasi. Pembagian kelompok ini secara umum tidak berhubungan nyata dengan jarak geografis, tetapi populasi-populasi yang berdekatan mempunyai kecenderungan untuk membentuk sub-kelompok tersendiri.

\section{UCAPAN TERIMA KASIH}

Penulis berterima kasih kepada teknisi laboratorium Genetika Molekuler Wahyunisari dan Triyanta yang membantu pekerjaan di laboratorium. 


\section{DAFTAR PUSTAKA}

Hamrick, J. L. 1989. Isozyme and the analysis of genetic structure in plant population. In Isozyme in Plant Biology. Soltis, D. E. and P. S. Soltis (ed). Dioscorides Press, Oregon, pp 87-105.

Hamrick, J.L. and M.J.W. Godt. 1989. Allozyme diversity in plants. In Plants Population GeneticsBreeding and Genetic Resources. A.H.D. Brown, M.T. Clegg, A.L. Kahler, and B.S. Weir (eds.). Sinauer. Sunderland. Massachusetts. pp.43-63.

Lande, R. C. and Shannon, S. 1996. The role of genetic variation in adaptation and population persistence in a changing environment. Evolution 50:434-437.

Lee, S-L., Kevin, K.S., and Saw, L-G. 2002. Population genetic of Intsia palembanica (Leguminosae) and genetic conservation of virgin jungle reserves in Peninsular Malaysia. Am. J. Bot. 89:447459.

Murray, M.G. and Thompson, W.F. 1980. Rapid isolation of high molecular weight plant DNA. Nuc. Acids. Res. 8. (19) : 4321-4325.

Nei M. 1972. Genetic distance between populations. American Naturalist 106: 283-292.

Nei, M. 1973. Analysis of gene diversity in-subdivided populations. Proc. Natl. Acad. Sci. USA 70:3321-3323.

Nei, M. (1978). Estimation of average heterozygosity and genetic distance from a small number of individuals. Genetics 89: 583-590.

Rimbawanto, A. dan Suharyanto. 2005. Keragaman genetik populasi Shorea leprosula Miq. dan implifikasinya untuk program konservasi genetik. Prosiding Seminar Nasional Peningkatan Produktivitas Hutan-Peran Konservasi Sumber Daya Genetik, Pemuliaan dan Silvikultur dalam Mendukung Rehabilitasi Hutan. E. B. Hardiyanto (ed.). Fakultas Kehutanan UGM dan ITTO.Yogyakarta. pp. 373-382.

Shashidhara, G., Hema, M. V., Ranjan, M. P. and Farooqi, A. A. 2003. RAPD analysis of genetic diversity in Santalum album. Plant \& Animal Genomes XI Conference, San Diego, CA.

Shiraishi, S and Watanabe, A. 1995. Identification of chloroplast genome between Pinus densiflora SIEB et ZUCC and P. thunbergii PARL. based on the polymorphisms in rbcL gene. J. Jpn. For. Soc. 77:429-436.

Suma, T. B. and Balasundaran, M. 2003. Isozyme variation in five provenances if Santalum album in India. Australian Journal of Botany 51:243-249.

Welsh, J. and McClelland, M. 1990. Fingerprinting genome using PCR with arbitrary primers. Nucleic Acid Research 18:7213-7218.

Williams, J. G. K., Kubelic, A.R., Livak, J. K., Ravalski, J. A. and Tingey, S. V. 1990. DNA polymorphisms amplified by arbitrary primer are useful as genetic marker. Nuc. Acid. Res. (18): 6531-6539p.

Yeh, F.C, Yang, R.C., Boyle, T.B.J., Ye, Z.H. and Mao, J.X. 1999. POPGENE 1.32 The User Friendly Shareware for Population Genetic Analysis. Molecular Biology and Biotechnology Center, University of Alberta, Edmonton. 